little, rather dingy, room in which, for well nigh thirty years, he has sat amidst blue-books, calendars, mineralogical specimens, and a rather orderly chaos of miscellaneous objects. They will think with sadness of the rupture of these old associations, and will follow to the grave with deep respect and sincere regret the old friend who has been so suddenly and unexpectedly removed from their midst.

\section{WILLIAM GEORGE VALENTIN}

$\mathrm{T}$ is with much regret that we record the untimely and sudden death on the rst inst. from apoplexy of Mr. William George Valentin. He was born in Neuenburg, in the Black Forest, on May 16,1829 . He came to England in 1855 , and, in the early days of the Royal College of Chemistry, studied under Dr. Hofmann, who esteemed him greatly, and, recognising his ability, made him senior assistant in the laboratory, a position which he retained at the Science Schools, South Kensington, under Dr. Frankland. He held for some years the office of gas examiner to the Great Western Gas Company, and at the time of his death was chemical adviser to the Trinity House.

His chemical text-books are deservedly popular; and within the last few days he corrected the final proofs of a new work which is therefore nearly ready for publication.

Mr. Valentin was a successful and painstaking teacher, and the fact that so many of the well-known chemists of this generation have received their early training from him, sufficiently indicates the value of his work; it would be difficult, indeed, to find one to whom the younger chemists of the present day are more indebted.

Within the last few weeks a few of his old friends and students of the Royal School of Mines had intended to present him with a testimonial; the efforts of the committee formed for this purpose will now be continued for the benefit of his widow and family.

\section{ELECTRIC LIGHTING}

$\mathrm{W}^{\mathrm{E}}$ need not insist on the extreme importance and interest of the exhibition which was opened last night at the Albert Hall, and for which extensive preparations have been making for some time. The public mind both in this country and abroad has been recently much agitated on the question of electric lighting, and, as night be expected, people are much confused among the many systems which have been brought forward, and even those who know something of the subject must find it difficult to make up their minds. Hence the importance of bringing together the various systems of electric lighting in such a way as to make comparison possible. It must, moreover, have an important educational influence upon the general public, helping somewhat to give them a truer idea of what physical science is, and what it is capable of doing for the good of mankind. The exhibition was opened last night by an able and interesting lecture by $\mathrm{Mr}$. W. H. Preece, the chair being occupied by the Prince of Wales.

The machines to be exhibited are not only those which have been recently attracting attention, but also older ones, which will exhibit in an impressive manner the history of the development of electric lighting. Thus there are in the arena of the Albert Hall specimens of Mr. Holmes's original magneto-electric machine, and of the Alliance Company's magneto-electric machine, lent by Trinity House, as well as the Siemens dynamo machine and the Gramme machine, now so much in use for generating electricity for lighting and other purposes. There are also varieties of the Gramme and Siemens ma chines, differing from each other more in minute detail than in general principle.

The Jablochkoff and the Lontin systems are also strongly represented. From the centre of the dome depend five large lamps of the Siemens pattern, round the upper corridor are ranged the Jablochkoff lamps exhibited by the Société Générale d'Electricité, and around the arena stand handsome specimens of the Lontin lamp, mounted on tastefully-designed posts. The Wilde lamp will also be strongly represented. This may be briefly described as the Jablochkoff candle with the central non-conducting substance left out. In addition to a powerful Gramme machine, the British Electric Light Company exhibit several lamps, notably the Serrin, hardly yet surpassed in some points of excellence, the Werdermann, Reynier, Higgins, and Rapieff lights, and it is stated that the Anglo-American Electric Light Company will exhibit the Wallace and the Iridium Incandescent lights, the last-named of which is of much the same kind as that employed by Mr. Edison. The distinguishing characteristics of these various lights were explained by Mr. W. H. Preece, and the exhibition, which will remain open to the public for the remainder of the week, promises to be by far the most attractive display of scientific apparatus made for some considerable time past.

It may not be inappropriate to give here a short account of a new form of electric lighting, which, it would seem, will not be represented at the exhibition now opened at the Albert Hall.

At last week's meeting of the Paris Academy, $M$. Jamin presented a model of an electric light for which he claims the greatest possible simplicity. The two carbons are kept parallel by two insulated copper tubes, separated by an interval of two or three millimeters, in which they slide by friction, and which serve at once to direct them and to guide the current. They are surrounded by a directing circuit composed of five or six spirals coiled on a thin rectangular frame $40 \mathrm{~m}$. long and $15 \mathrm{~m}$. broad. This circuit, traversed by the same current as the carbons, and in the same direction, guides. and fixes the electric arc at the extremity of the points. The lighting is effected automatically. For this purpose, the two extremities of the carbons are surrounded by a thin caoutchouc band which keeps them close together. Between them, a little above, a small fragment of iron wire is introduced, which keeps them in close communication by a single point. As soon as the circuit is closed, the current traverses this wire, makes it red-hot, and melts the caoutchouc; the two carbons, thus freed, separate, and the arc is established with a sort of explosion. Carbons of any size may be employed, up to $8 \mathrm{~mm}$. diameter. At this limit the waste scarcely exceeds $08 \mathrm{~m}$. per hour. By a proper arrangement the points may be maintained in their initial position. The apparatus may be suspended either with the points upwards or directed towards the ground. For several reasons, which Mr. Jamin states, the latter position is preferable. With its points downwards, then, M. Jamin claims for his light the following advantages:- $\mathrm{I}$. That of simplicity, since it requires no mechanism and no preliminary preparation; all is reduced to a support and to carbons ; (2) that of mechanical economy, since it succeeds in almost doubling the number of lights; (3) increase of illumination, since each of the new lights is nearly twice as powerful as the old; (4) quality of light, which is more white; (5) a more advantageous arrangement of the poles, which throw their greatest amount of light downwards, where it is required, instead of losing it towards the sky, where it is useless; (6) finally, economy of the combustible material, since the waste is less in proportion to the size of the carbons.

\section{NOTES}

WE greatly regret to announce the death at Rome, on April 14 of Prof. Paolo Volpicelli, the well known Italian electrician. We hope to be able to give details of his life and work in an early number. 